\title{
ON ATCO GaS AND PIPELINES: \\ A RePly to Professor WOOLley
}

\author{
H. MARTIN KAY, Q.C.
}

\section{INTRODUCTION}

In her article entitled '“Practical Necessity' or 'Highly Sophisticated Opportunism' Judicial Review and Rate Regulation After ATCO Gas and Pipelines Lrd. v. Alberla (Energy and Urilities Board),"' Professor Alice Woolley is sharply critical of the majority decision of the Supreme Court of Canada, arguing that the case represents several major changes to the law.

Professor Woolley criticizes the majority's approach to determining the standard of judicial review, maintaining that "[i]t suggests a reanimation in substance of the 'jurisdictional question' approach,"2 but she fails to recognize that "a general grant of 'public interest' jurisdiction"1 does not extend the jurisdiction of the regulatory body beyond its enabling legislation. She also argues that the decision will have an impact on how the Alberta Energy and Utilities Board (AEUB) approaches "asset disposition and cost of service ratemaking"- and on the "understanding of the relationship between ratepayers and the utility" underlying "initiatives to introduce increased competition and deregulation," contrary to the author's apparent misgivings. If the decision in fact does so, it would only bring the approach or understanding into conformity with long-standing legal principles.

The asset at issue, lands and buildings acquired over the period 1922 to 1965 (at a time with different ratepayers (customers) from those claiming the proceeds), constituted a city block near downtown Calgary. Commercial buildings were constructed by new owners after the sale was approved. The lands were carried in the rate base until disposition at their original acquisition cost (CDN\$83,720); only the buildings were depreciated. In conjunction with the approval of the sale to new owners, there was a finding that the sale would not result in harm to ratepayers. The AEUB then allocated one-third of the appreciation of the land (which formed the major part of the asset) and buildings to the utility and two-thirds as a credit to ratepayers, benefiting the current ratepayers by lower increases to utility rates.

The majority of the Supreme Court of Canada in dismissing the appeal upheld in large part the decision of the Alberta Court of Appeal, which found that the AEUB erred in law in

- Counsel for ATCO Gas and Pipelines in the Supreme Court of Canada decision.

' Alice Woolley. "'Practical Necessity' or 'Ilighly Sophisticaled Opportunism"?: Judicial Review and Rate Regulation After ATCO Gas and Pipelines Led. vi. Alherla (Energy and Utilities Board)" (2006) 44 Alta. L. Rev. 445; ATCO Gas and P'ipelines L.d. v. Alherla (Energy and Urilities Board), 2006 SCC 4, [2006] I S.C.R. 140 [ATCO Gas (SCC)].

Woolley, ibid. at 445 .

Ibid.

Ibid.

Ibid. 
allocating the proceeds of the sale of land and buildings owned by ATCO. The dissenting opinion of the Supreme Court accepted the Board's authority to impose the conditions as to allocation on the approval of the sale.

Professor Woolley, in treating ATCO Gas (SCC) as a radical departure from the contemporary approach to determining the standard of judicial review, has made much more of the decision than is warranted. Her analysis misstates significant aspects of the rate-setting process, which results in treating the decision as radical. As a Supreme Court decision it is no doubt important, but it is hardly radical or surprising.

\section{The Standard Of JUdicial REview}

Whether the AEUB had the authority to allocate proceeds is a question of law and, subject to other factors, the standard of review is correctness. Alone among all the justices of the Supreme Court of Canada and the Alberta Court of Appeal who decided the case, as well as the parties to the appeal, Professor Woolley asserts that the standard applied to judicial review in ATCO Gas (SCC) is a throwback to an earlier age when characterization of the question determined whether the matter went to the tribunal's jurisdiction. Explicitly cautioning against "a hasty characterizing of the issue as 'jurisdictional,"'7 Bastarache J., for the Supreme Court majority, undertook a full pragmatic and functional analysis, concluding that the appropriate standard was correctness, a conclusion with which the dissenting judges agreed. $^{8}$

Professor Woolley's own analysis, however, conflates the AEUB's acknowledged expertise when acting within the scope of its powers with the application of that expertise in determining the scope of its authority. She makes the tribunal's expertise the predominant factor in determining its legislative jurisdiction. Her statement that the Supreme Court did not have the expertise to make the initial determination and thus could not do so "properly" compared to the AEUB ignores that the issue involves a consideration of the scope of legislative power, something the Court is requested to do, and is more experienced at doing than the AEUB. The AEUB's own specific and technical expertise, fully recognized by the Court, does not determine the initial question of whether it is acting within its jurisdiction and is correct in law.

\section{The Power to Impose Conditions in the PUblic INTERest}

Surprisingly, Professor Woolley criticizes the majority's conclusion that the broadly worded "public interest jurisdiction" must be exercised only within the AEUB's legislative

ATCO Gas and Pipelines LAd. v. Alberla (Energy and Uilitics Board), 20044 ABCA 3, 339 A.R. 250 [ATCO Gas (ABCA)]. The majority of the Supreme Court held that the Court of Appeal did not err in concluding that the AEUB had acted beyond its jurisdiction in allocating the proceeds, but it lueld the Court of Appeal did err in not holding that the AEUB had no jurisdiction to allocate any portion of the profits to ratepayers. The Court of Appeal concluded that the AEUB could allocate the depreciation on the buildings to the rate base, but not the profit on the sale of the land. ATCO Gas was successful in its cross-appeal of this aspect of the Court of Appeal's decision.

- ATCO Gas (SCC), supra nole 1 at para. 23.

Ibid. at paras. $32,103$. 
mandate to principally set rates. She bestows that which the Legislature has not: the authority for the AEUB to set conditions in the public interest to expand the tribunal's jurisdiction. If the statutory scheme of regulation is ignored, it is impossible to define any limits to the AEUB's mandate. Wisely, the rights and freedoms existing at common law, as established by the courts, have protected against such intrusions upon property rights and economic freedoms for centuries.' The real significance here may lie in the fact that the Courts have explicitly done so in the face of a modern statutory scheme of regulation.

\section{Respect for Property RightS}

It is not an overreaction to define the AEUB's allocation of proceeds in their decision as the confiscation of property from the regulated owner. It is an accepted rate-making principle that ratepayers acquire no interest in the property of the utility owner. Their rates pay for services. Accordingly, to imply that the power to allocate the proceeds includes a power to impose conditions is to ignore the principle that property cannot be expropriated without compensation unless explicit statutory language permits it. ${ }^{10}$

The majority of the Supreme Court agreed that "[t]he property in question is as fully the private property of the owner of the utility as any other asset it owns. Deployment of the asset in utility service does not create or transfer any legal or equitable rights in that property for ratepayers. Absent any such interest, any taking such as ordered by the Board is confiscatory." In so doing, the Court endorsed the decisions of the Alberta Court of Appeal as well as the United States Supreme Court which had been quoted by Wittman J.A. as follows: "Customers pay for service, not for the property used to render it [...] By paying bills for service they do not acquire any interest, legal or equitable, in the property used for their convenience or in the funds of the company."12

With the property rights clearly established, the Supreme Court of Canada relied upon the considerable body of authority cited in support of the following proposition:

It is well established that potentially confiscatory legislative provision ought to be construed cautiously so as not to strip interested parties of their rights without the clear intention of the legislation.... Not only is the authority to attach a condition to allocate the proceeds of a sale to a particular party unnecessary for the Board to accomplish its role, but deciding otherwise would lead to the conclusion that a broadly drawn power can be interpreted so as to encroach on the economic freedom of the utility, depriving it of its rights. This would go against the above principles of interpretation. ${ }^{13}$ 


\section{AUTHORITY TO ADDRESS HARM}

The Supreme Court ruled that, even if the Board did have jurisdiction, the result would have been the same. Once there is a finding of no harm, there is no legitimate basis upon which the AEUB could impose conditions. If harm or deprivation result, the Court was firm that the AEUB had ample authority to address it. The AEUB does not need to allocate proceeds to "ameliorate the impact of a disposition": ${ }^{4}$ it can simply condition approval upon the utility adopting appropriate remedial measures, which may involve the expenditure of funds. As it is, when the AEUB approved the disposition of the assets here, it found that the "no harm" test was met. ${ }^{15}$ Thus even on Professor Woolley's view, there should be no justification for any allocation.

Moreover, the majority found that any allocation would have been unreasonable since "it [the Board] wrongly assumed that ratepayers had acquired a proprietary interest in the utility's assets." 16

\section{RETROACtive RATE-MAKING}

The Supreme Court's decision recognized a second fundamental principle in utility law: the prohibition against retroactive rate-making. The dissenting opinion contended that the Board's broad powers to fix future rates as well as its general supervision of all gas utilities and its owners obviated any allegation of "impermissible 'retroactive rate-making."'17 This seems incompatible with the Court's earlier decisions on the point, as utility boards have always had broad policy objectives. The Court noted:

The Board was secking to rectily what it perecived as a historic over-compensation to the utility by ratepayers. There is no power granted in the various statutes for the Board to execute such a relind in respect of an erroneous perception of past over-compensation. It is well established throughout the various provinces that utilities boards do not have the authority to retroactively change rates.... But more importantly, it cannot even be said that there was over-compensation: the rate-setting process is a speculative procedure in which both the ratepayers and the shareholders jointly carry their share of the risk related to the business of the utility. $^{18}$

The expansive view of the Board's broad regulatory powers therefore, were limited here as well by common law principles and statutory presumptions which have historically protected both individual and corporate economic rights and freedom.

The fixing of rates establishes the rights and obligations of the ratepayers and the utility. If the rates are fair and reasonable, there is no basis upon which to allow ratepayers to participate in the proceeds of sale, since that implies that the ratepayers overpaid or were entitled to a refund. The dissenting view that ratepayers are entitled to participate does not explain how this concept fits with the process which fixes rates for the regulated service.

\footnotetext{
it Woolley, supra note 1 at 452.

13 ATCO Gas (SCC), supra note 1 at para. 83.

10 $\quad$ bid. at para. 83.

19 Ibid. at para. 93.

is Ibid. at para. 7I [references omitted].
} 


\section{THE TREATMENT OF RATE BASE, ASSUMPTION OF RISK, AND USED AND USEFUL.}

Ratepayers in an original cost jurisdiction, like Alberta, are insulated from any increase in rates due to increases in the value of the lands or other property used. Accordingly, Professor Woolley's statement that "all fluctuations in value of an asset held by a utility are absorbed by ratepayers,"19 leads to unwarranted criticism of the majority approach. In Alberta, no account is taken in fixing rates of increases or decreases based on the current market value of assets. The raw lands were worth CDN\$6 million at the time of sale. Ratepayers only paid a return on the total purchase price of CDN\$83,720 throughout decades in regulated service. The ratepayers over that long period cannot be said to have "absorbed" any of the value of that asset since land is non-depreciable.

Professor Woolley states that assets remain in the rate base whether they continue to be used and useful and that the utility continues to earn a rate of return on these assets. She explains this principle by reference to a pipeline no longer offering the most efficient service. This example refers to a pipeline which is a core utility asset. ${ }^{20}$ Lands and buildings are not core utility assets. They can readily go in and out of rate base without diminishing the regulated service. The AEUB is obliged to consider whether the costs of items the utility seeks to place or continue in the rate base continue to be used and useful. Where it is feasible to change to more efficient ways of meeting a utility need, the AEUB would expect the owner to make the change. In fact, the lands and buildings sold here were replaced with leased premises expected to meet the same needs at lower costs. Professor Woolley's comments are an oversimplification of a complex issue and lead to a misleading analysis of the inclusion of assets in the rate base under the "used and useful" concept.

\section{OTHER IMPIICATIONS}

Professor Woolley sees dark days ahead as a result of ATCO Gas and Pipelines, including changes to the AEUB's approach to a utility's rate base and to depreciation, as well as to the future of deregulation and competition. She is critical that "this kind of sea-change in a longstanding approach to a regulatory problem is properly instigated by a court in a judicial review proceeding on a relatively narrow issue."21 With respect, she fails to acknowledge the issue as the Supreme Court saw it. The breadth of delegated powers under a modern regulatory statute could not override property rights and economic freedoms unless the legislation was explicit in this regard or it was necessary in order to carry out its objects. Both the Alberta Court of Appeal and the Supreme Court of Canada are hardly on unfamiliar ground in this respect. In its other aspects, her article is really a "straw man" controversy, based on confusion about the role of tribunal expertise in determining jurisdiction compared to its role in the excrcise of jurisdiction, and the fundamental nature of the Alberta utility rate-setting process. 